\author{
ACTA MYCOLOGICA \\ Vol. 46 (2): 201-210 \\ 2011
}

\title{
Ophiostomatoid fungi isolated from fallen shoots of Scots pine pruned by Tomicus species in Poland
}

\author{
ROBERT JANKOWIAK ${ }^{1}$ and MIROSLAV KOLAŘÍK ${ }^{2}$ \\ ${ }^{1}$ Agricultural University of Cracow, Department of Forest Pathology \\ Al. 29 Listopada 46, 31-425 Kraków, rljankow@cyf-kr.edu.pl \\ ${ }^{2}$ Institute of Microbiology v.v.i, Academy of Sciences of the Czech Republic \\ Vídeňská 1083, 14220 Prague 4, Czech Republic
}

Jankowiak R., Kolařík M.: Ophiostomatoid fungi isolated from fallen shoots of Scots pine pruned by Tomicus species in Poland. Acta Mycol. 46 (2): 201-210, 2011.

Ophiostomatoid fungi are known to be associated with Tomicus spp. on Pinus sylvestris. However, very little is known about the fungi present in the pine shoots damaged by these insects. The aim of this study was to survey species of Ophiostoma s.l. associated with fallen shoots of Scots pine pruned by Tomicus spp. in Poland. The study was conducted in four pure Scots pine stands in southern and south-western part of the country. Fungi were identified based on morphology and DNA sequence comparison for two gene (the ITS rDNA region and B-tubulin). In total, 64 isolates obtained, represent seven species of ophiostomatoid fungi, including their asexual states of the genera. Two of them, Ophiostoma sp. 1 and Sporothrix sp. 1 probably represent new taxa. All species were found at very low frequencies. Among them, Ophiostoma minus, Ophiostoma sp. 1 and Sporothrix sp. 1 were the most frequently isolated, with a frequency of $2.0 \%$. Occasionally, isolated species were: Leptographium piriforme, Ophiostoma canum, O. floccosum and Grosmannia cucullata-like. Association of species of Ophiostoma s.l. with Tomicus spp. and the taxonomic status of two new species are discussed.

Key words: Ophiostoma, Sporotrix, Pinus sylvestris, new taxa, bark beetles

\section{INTRODUCTION}

Many species of bark beetles (Coleoptera: Scolytinae) have been reported from pine stands of Poland. These insects are generally considered secondary colonizers, which attack stressed, dying or dead trees. Among them, Tomicus piniperda (L.) and T. minor (Hart.) are able to attack healthy standing Scots pine trees under favourable conditions. The damage by bark beetles of the genus Tomicus in pine trees is caused by two feeding strategies. As in many species of bark beetles 
one strategy is penetration of the protective bark and nutritive phloem of tree stems, and transmission of blue-stain fungi in the sapwood. Another strategy occurring only in Tomicus beetles is penetration and maturation feeding of adults in living shoots of healthy trees. The shoots become hollow and easily break off. During this period of maturation-feeding, each new adult feeds on the currentyear or last year's shoots, mostly in the upper half of the crown. Adults bore into the bark of shoots and hollow out the pitch to a length of $2-3 \mathrm{~cm}$. At strong winter, most of the injured shoots break off and fall to the ground. When shoot feeding is severe, tree height and diameter growth are reduced (Borkowski 2001).

Species described in the past in the genus Ophiostoma s.l. represent a group of morphologically similar genera characterized by ascomata with elongated perithecial necks. In fact, according to the recent taxonomic studies most of them belong to the genus Ophiostoma Syd.\& P. Syd. s. str. with Pesotum J.L. Crane \& Schokn. and Sporothrix Hektoen \& C.F.Perkins anamorphs, Grosmannia Goid. with Leptographium Lagerb. \& Melin anamorphs and Ceratocystiopsis H. P. Upadhyay \& W. B. Kendr. with Hyalorhinocladiella H.P. Upadhyay \& W.B. Kendr. anamorphs (Upadhyay 1981; Zipfel et al. 2006). These genera and the members of the genus Ceratocystis Ellis \& Halst. s. str. have been referred to as the ophiostomatoid fungi (Wingfield et al. 1993). Ophiostomatoid fungi are the predominant associates of Tomicus Latreille in Europe. Specific relationships between fungi and Tomicus spp. are the most clear for T. minor. The ambrosia fungus, Ambrosiella tingens (Lagerb. \& Melin) L.R. Batra and Ophiostoma canum are common and consistent associates of T. minor in Europe (Mathiesen 1950, 1951; Francke-Grosmann 1952; Mathiesen-Käärik 1953; Kotýnková-Sychrová 1966; Kirisits et al. 2000; Jankowiak 2008). In the recent studies, the association of T. minor also with Ophiostoma minus, O. piceae (Münch) Syd. \& P. Syd., Leptographium procerum (W.B. Kendr.) M.J. Wingf., L. lundbergii Lagerb. \& Melin (Jankowiak 2008) and Ophiostoma canum-like species (Linnakoski et al. 2010) has been reported. The association between T. piniperda and ophiostomatoid fungi is looser because this insect carries numerous fungal species, but with low and inconsistent frequency. Among them, O. minus and Leptographium wingfieldii M. Morelet were dominant fungal species in many populations in Europe (Lieutier et al. 1989; Gibbs, Inman 1991; Solheim, Långström 1991; Wingfield, Gibbs 1991; Jankowiak 2006; Jankowiak, Kurek 2006; Jankowiak, Bilański 2007).

Although Tomicus spp. mycobiota is relatively well recognized in Europe (Kirisits 2004), we have no information about fungal taxa associated with pine shoots damaged by these insects. It is unknown whether shoots damaged by adult individuals feeding in Scots pine crowns are colonized by fungal species carried by Tomicus beetles. We often observed that numerous arthropods penetrated fallen pine shoots and therefore we presume that these organisms can act as vectors for fungal species not closely associated with Tomicus spp.

The studies were aimed to survey the ophiostomatoid fungi associated with pine shoots damaged by Tomicus spp. collected from Poland. We determined isolates to the species level using their morphological characteristics, as well as DNA sequencing data. 


\section{MATERIALS AND METHODS}

Isolation of fungi from pine shoots. The investigations were carried out in 20072008 in four pure Scots pine stands in Poland (Fig. 1). In October, the fallen Scots pine shoots (100 per site) damaged by beetles were gathered from the forest floor and placed in separate clean paper bags. Later, shoots were stored for maximum 48 hours in a cool room at $4^{\circ} \mathrm{C}$ until they were used for the fungi isolation.

Shoot samples were cut into $5 \mathrm{~cm}$ long sections and surface disinfected by immersing in $95 \%$ ethyl alcohol. After drying, small pieces of shoots (about $5 \times 5 \mathrm{~mm}$ ) were removed from each shoot section (six pieces per one shoot) and placed in Petri dishes containing a selective medium for Ophiostoma spp. (20 g malt extract, $20 \mathrm{~g}$ agar, and $1 \mathrm{~L}$ distilled water, amended with $0.05 \%$ cycloheximide). Resulting isolates were purified by transferring mycelium from the edges of single colonies to fresh $2 \%$ MEA (Tab. 1). The representative strains were deposited in the Culture Collection of Fungi, Department of Forest Pathology, Agricultural University of Cracow.

Culture morphology and DNA sequencing. Isolates were initially identified and grouped based on the culture morphology. Representatives of each of the groups obtained were selected for DNA sequencing (Tab.1).

Fungi were identified on the basis of morphological characteristics by comparison with published data and reference cultures deposited at Department of Forest Pathology, Agricultural University of Cracow.

Identification based on morphology was confirmed by DNA sequencing of the representative isolates (Tab.1). ITS rDNA region (ITS1-5.8 S-ITS2) were amplified using the primers ITS1 and NL4 as described by Kolařík et al. (2006). A partial B-tubulin sequence was determined for a subset of isolates, including an unknown Ophiostoma sp. 1 and Sporothrix sp. 1 isolates using the primers T1 or bt2a and bt2b (Glass, Donaldson 1995; O’Donnell, Cigelnik 1997). The amplicons were purified and both strands were sequenced using the same primers by Macrogen Inc. (Seoul, Korea). The sequences were compared with data from GenBank using a Blast similarity search. Sequences generated in this study and sequences of other, related species from GenBank were aligned using Clustal W (Thompson et al. 1994). Phylogenetic trees were constructed with MEGA 5.04 using the Neighbour-joining (NJ) method and Kimura two-parameter with a transition to transversion ratio $(\mathrm{Ti} / \mathrm{Tv}=2)$ (Tamura et al. 2011). Bootstrap values were calculated for 1000 replications.

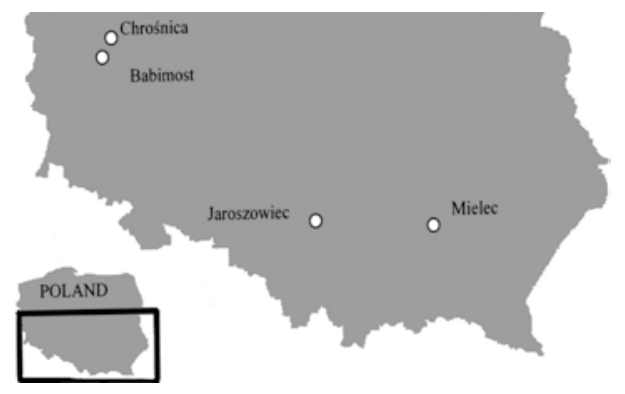

Fig. 1. Map of sampling sites: Chrośnica $\left(15^{\circ} 59^{\prime} 36^{\prime \prime} \mathrm{N}, \quad 52^{\circ} 17^{\prime} 13^{\prime \prime} \mathrm{E}\right)$; $\quad$ Babimost $\left(15^{\circ} 50^{\prime} 33^{\prime \prime} \mathrm{N}, 52^{\circ} 09^{\prime} 11^{\prime \prime} \mathrm{E}\right)$, Jaroszowiec $\left(19^{\circ}\right.$ $\left.36^{\prime} 45^{\prime \prime} \mathrm{N}, 50^{\circ} 20^{\prime} 18^{\prime \prime} \mathrm{E}\right)$, Mielec $\left(21^{\circ} 29^{\prime} 36^{\prime \prime} \mathrm{N}\right.$, $\left.50^{\circ} 18^{\prime} 53^{\prime \prime} \mathrm{E}\right)$. 


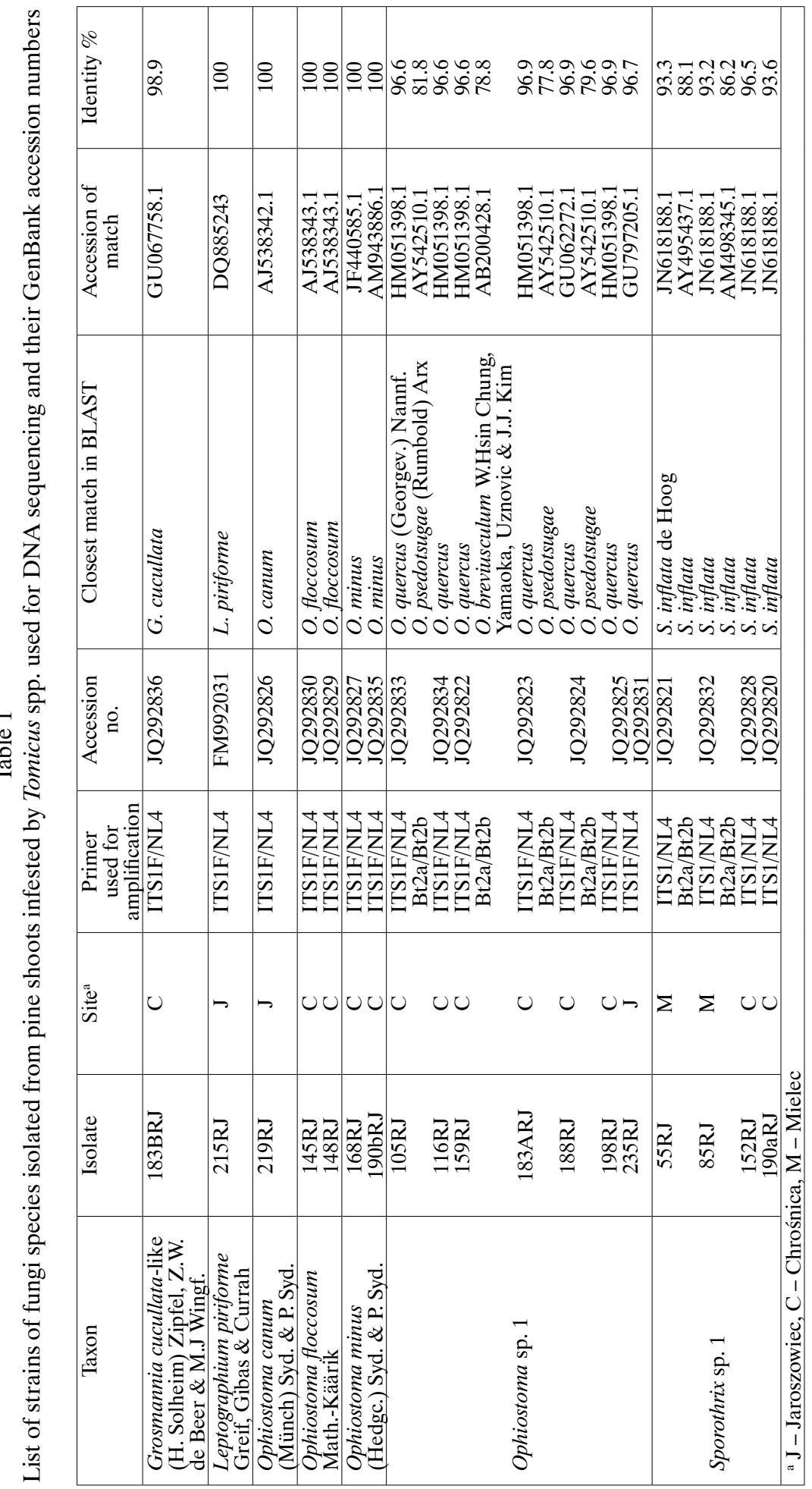




\section{RESULTS}

Identification of ophiostomatoid species. Morphological investigation showed that seven ophiostomatoid species were collected, namely Leptographium piriforme, Ophiostoma canum, O. floccosum, O. minus, Grosmannia cucullata-like and two unknown fungi, Ophiostoma sp. 1 and Sporothrix sp. 1.

Strain classified as Grosmannia cucullata-like produced in culture dark brown perithecia with straight or curved neck ended ostiolar hyphae. Ascospores were hyaline, onecelled, lunate, with a thick hyaline sheath. This fungus formed Pesotum anamorph, stipe branched at the apex, with cylindrical conidia (Figs 2-5). Sporothrix sp. 1 (Fig. 6) was characterized by producing micronematous conidiogenous cells arising orthotropically from undifferentiated hyphae. Conidia were produced directly on denticles, clavate; no ascomata were observed. Strains referred to as Ophiostoma sp. 1 presented both Pesotum and Sporothrix synanamorphs in culture (Figs 7-10) while no ascomata were observed. Conidiophores were synnematous, branched at the apex, single but often also in loosely arranged groups. Conidiogenous cells of Sporothrix state were micronematous, mononematous, hyaline, arising ortho- or slightly plagiotropically from undifferentiated aerial hyphae. Conidia were produced directly on denticles, clavate, slightly curved.

Comparison of ITS sequences obtained for isolates in this study, with sequences from GenBank, indicate that our isolates could also be assigned to seven taxa. DNA sequences of the majority of species identified here were identical with reference sequences, confirming their identity (Tab. 1). ITS rDNA sequences of G. cucullata-like isolate showed $99 \%$ similarity with G. cucullata strains from GenBank. In the ITS tree, Ophiostoma sp. 1 grouped most closely to Ophiostoma quercus in O. piceae complex (Fig. 11). Similarity search using a B-tubulin showed highest relatedness with Ophiostoma pseudotsugae $(<81.8 \%)$ and Ophiostoma breviusculum (78.8\%) (Tab. 1). Based on sequence data of the ITS regions and $\beta$-tubulin, the unknown Sporothrix sp. collected by us was most closely related to $S$. inflata and $S$. schenckii in $S$. schenckii-O. stenoceras complex (Tab. 1, Fig. 11).

Isolation frequency. All the species were found at very low frequency (Tab. 2). In culture, $43 \%$ (28 isolates) of a total of 64 fungal isolates obtained from pine shoots

Table 2

Number of isolates and frequency (in parentheses) ${ }^{*}$ of fungi species associated with pine shoots infested by Tomicus spp.

\begin{tabular}{|l|c|c|c|c|c|}
\hline \multirow{2}{*}{ Fungal species } & \multicolumn{4}{c|}{ Sites } & \multirow{2}{*}{ Total } \\
\cline { 2 - 5 } & Mielec & Chrośnica & Jaroszowiec & Babimost & \\
\hline Grosmannia cucullata-like & & $1(1)$ & & & $1(0.3)$ \\
\hline Leptographium piriforme & $1(1)$ & & $2(2)$ & & $3(0.8)$ \\
\hline Ophiostoma canum & & $1(1)$ & $3(1)$ & & $4(1.0)$ \\
\hline Ophiostoma floccosum & & $2(2)$ & & & $2(0.5)$ \\
\hline Ophiostoma minus & & $2(2)$ & $10(5)$ & $3(1)$ & $15(2.0)$ \\
\hline Ophiostoma sp. 1 & $17(6)$ & & $11(2)$ & $28(2.0)$ \\
\hline Sporothrix sp. 1 & 2 & 29 & 15 & $4(4)$ & $11(2.0)$ \\
\hline Total no. isolates & $100(600)$ & $100(600)$ & $100(600)$ & $100(600)$ & $400(2400)$ \\
\hline $\begin{array}{l}\text { Total no. shoots and shoot } \\
\text { fragments (in parentheses) }\end{array}$ & & & & & 64 \\
\hline
\end{tabular}

Frequency $=($ No. of shoots from which a particular fungus was isolated/Total number of shoots $) \times 100$ 


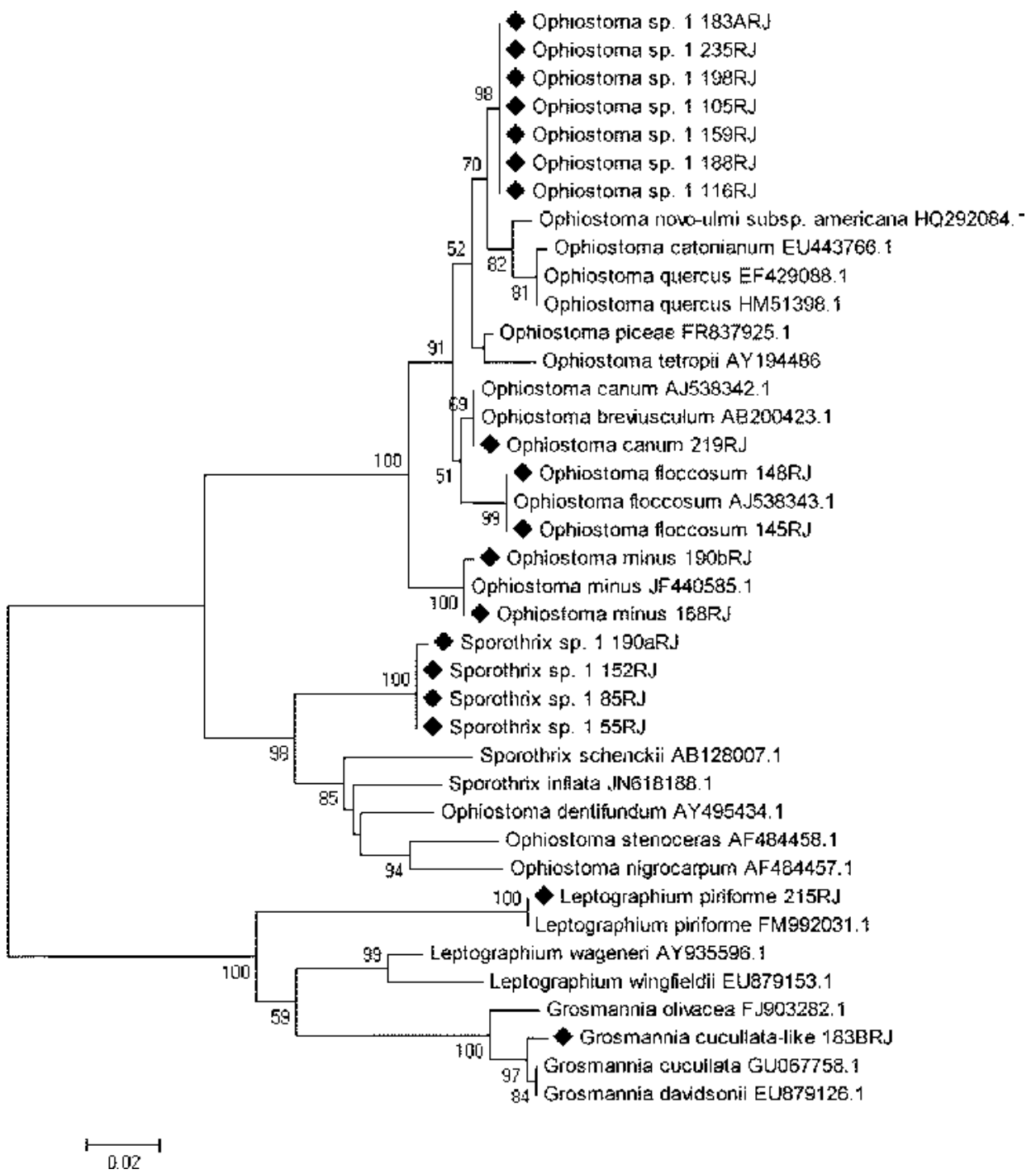

Fig. 11. Phylogram obtained from Neighbour-joining analyses of DNA sequences of nuclear ITS region. Bootstrap support values (1000 replicates) above $50 \%$ are indicated at the nodes. Isolates with markers represent those collected and sequenced in this study.

infested by Tomicus spp. in Poland, represented Ophiostoma sp. 1. This species was isolated from shoots with an average isolation frequency of $2 \%$ (from $0 \%$ at Jaroszowiec to $6 \%$ at Chrośnica). The second most frequent species (15 isolates) was $O$. minus, with frequencies ranging from $0 \%$ at Mielec to $5 \%$ at Jaroszowiec. The third taxon, Sporothrix sp. 1 (11 isolates) occurred at an average frequency of $2 \%$ (from $0 \%$ Jaroszowiec to $4 \%$ Babimost). Leptographium piriforme, O. canum, G. cucullatalike strain and $O$. floccosum were isolated from shoots infested by Tomicus spp. with very low frequencies (Tab. 2). 

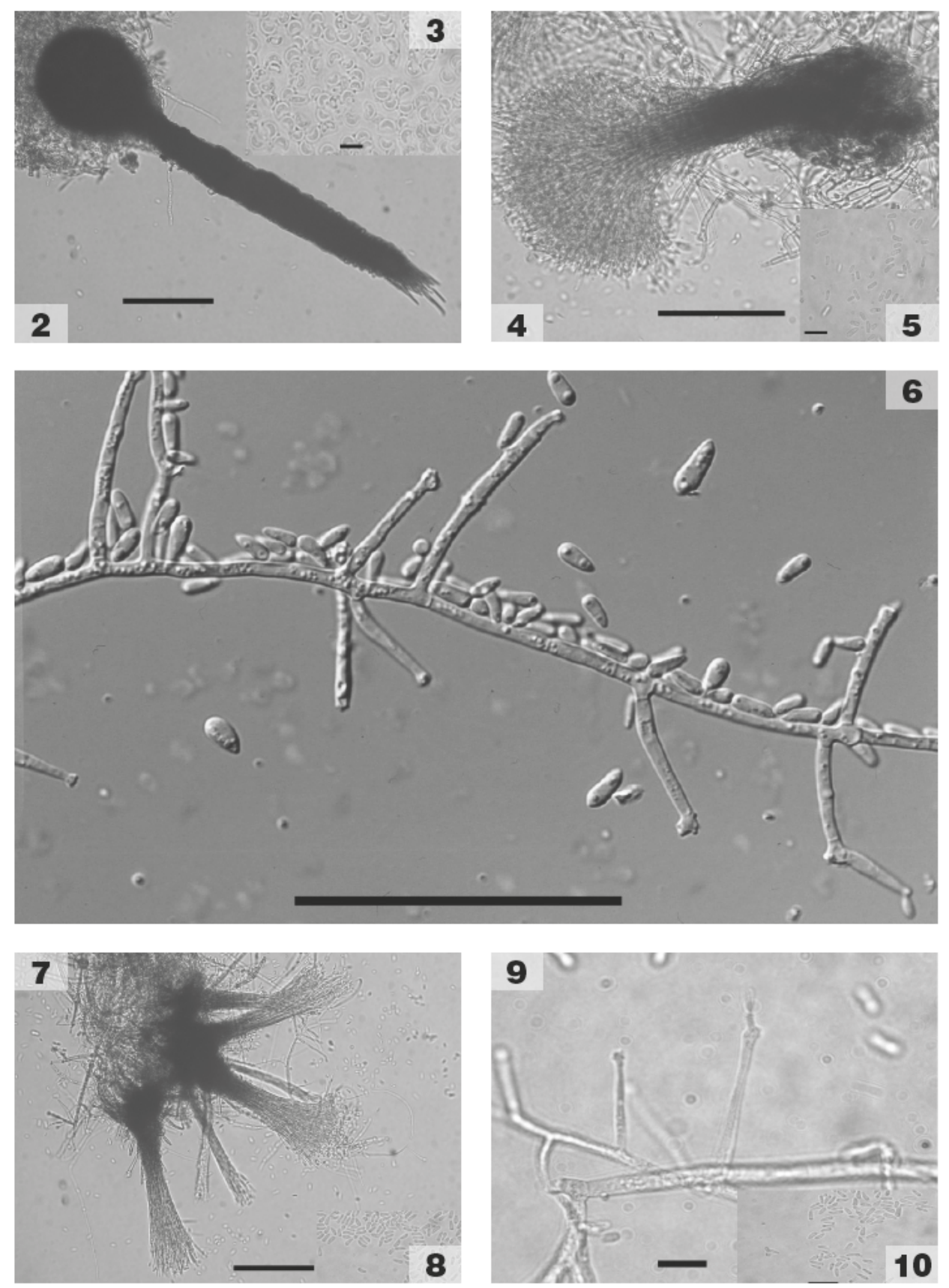

Figs 2-5. Grosmannia cucullata-like, (photo by R. Jankowiak): 2. Ascocarp (scale bar $=100$ $\mu \mathrm{m}), 3$. Ascospores (scale bar $=10 \mu \mathrm{m}), 4$. Pesotum anamorph (scale bar $=100 \mu \mathrm{m}), 5$. Conidia (scale bar $=10 \mu \mathrm{m}$ ). Fig.6. Sporothrix sp.1 (photo byT. Kowalski): conidiogenous cell with conidia $($ scale bar $=100 \mu \mathrm{m})$. Figs $7-10$. Ophiostoma sp.1 (photo by R. Jankowiak): 7. Pesotum anamorph (scale bar $=100 \mu \mathrm{m}), 8$. Conidia (scale bar $=10 \mu \mathrm{m})$, 9. Sporothrix synanamorph $($ scale bar $=100 \mu \mathrm{m}), 10$. Conidia (scale bar $=10 \mu \mathrm{m})$. 


\section{DISCUSSION}

This is the first survey of ophiostomatoid species associated with pine shoots damaged by adult individuals of Tomicus spp. yielded in 64 strains isolated from four pine forests stands in Poland. Based on morphological characteristics and DNA sequence comparison, four species of the genus Ophiostoma s.str. and after one Grosmannia, Leptographium and Sporothrix were confirmed as associated with fallen pine shoots. Three species, namely $O$. canum, $O$. floccosum and $O$. minus, have previously been recorded in Europe in association with Tomicus spp. beetles (Kirisits 2004). However, O. floccosum is reported here for the first time from Poland. This fungus is widely distributed in Europe primarily on pine trees, but usually it is recorded at low frequency (Linnakoski et al. 2010).

Two species, Ophiostoma sp. 1 and Sporothrix sp. 1 probably represent new taxa. According to molecular data, isolates of Ophiostoma sp. 1 obtained in this study resided in the $O$. piceae-complex including species having allantoid ascospores and both Pesotum and Sporothrix synanamorphs. Ophiostoma sp. 1 seems to be closely related to $O$. quercus. The morphological characteristics of Sporothrix sp. 1 broadly resemble species of the $S$. schenckii-O. stenoceras complex. Sequence data and phylogenetic analyses also placed Sporothrix sp. 1 in the $S$. schenckii-O. stenoceras complex. Sequences of Sporothrix sp. 1 even formed a separate lineage within $S$. schenckii-O. stenoceras complex.

Only single isolate represented Grosmannia cucullata-like, thus its taxonomical status remains unclear and requires confirmation based on greater number of isolates. Based on ITS sequences this strain is closely related to isolates of G. cucullata. This species was also morphologically similar to G. cucullata but had shorter perithecial neck and larger ascospores. Grosmannia cucullata has been reported from Picea abies (L.) Karst., P. sylvestris and Larix decidua Mill. in association with various species of bark beetles (Kirisits 2004) and cerambycids (Jankowiak, Kolařik 2010a). The taxonomic position of Ophiostoma sp. 1, G. cucullata-like and Sporothrix sp. 1 will be further discussed after a more critical study has been concluded.

We presumed that new T. piniperda and T. minor individuals may efficiently introduce spores of ophiostomatoid fungi to young pine shoots during maturationfeeding. Unexpectedly, the frequencies of the ophiostomatoid species were very low. None species was consistently isolated from each of the studied pine stands. Unfavorable growth conditions in very fresh tissues of shoots could be the reason the lower than expected frequency of these fungi. Our study demonstrates that among fungal associates of Tomicus spp. in Poland only $O$. minus may infest fresh pine shoots during maturation-feeding. These results confirmed the findings of Jankowiak and Kurek (2006), who isolated O. minus from T. piniperda galleries at relatively high frequencies in 10 weeks after the main beetles attack. The ability of $O$. minus to colonize the shoots results from its ability to tolerate low concentration of oxygen (Solheim et al. 2001). This physiological feature agreed with the high level of virulence of this species to pine (Lieutier et al. 1989; Solheim, Långström 1991; Solheim et al. 1993; Solheim et al. 2001; Jankowiak et al. 2007). However, low and very variable frequency of $O$. minus indicates that its role in damaging of pine shoots during the shoot feeding phase is rather limited. 
Our studies showed that shoots laying on the forest floor may be relatively often colonized by ophiostomatoid fungi that are not closely associated with Tomicus spp. beetles, primarily by Ophiostoma sp. 1 and Sporothrix sp. 1. Ecology of these fungi is however unknown. We presume that various antropods as spiders, ants and dipterans may vectored propagules of ophiostomatoid species. In nature, we often observed unidentified spiders in the pitch of shoots damaged by Tomicus spp. Similar observations were made by Greif et al. (2006), who isolated L. piriforme from various arthropods taxa. The presence of $L$. piriforme in pine shoots demonstrated in our study, could be the result of such vectoring as well. Interestingly, this fungus has been described by Greif et al. (2006) from various arthropods collected in an aspen-dominated forest in western Canada and until 2010 it has been known only from this country. Our study showes that $L$. piriforme occurs pine forest habitat in Europe and may suggest that the species can develop on a wider range of host plants. Its pathogenicity has not been fully recognized yet. According to Jankowiak and Kolařik (2010b), L. piriforme appears to be a weak pathogen of Pinus sylvestris.

Sporothrix species placed in the $O$. stenoceras-S. schenckii complex are reported to live mostly as saprotrophs on wood or as soil fungi (de Beer et al. 2003). Six species that had been isolated directly from soil but one of the recent studies (de Meyer et al. 2008) have revealed next three new species associated with wood and soil: Sporothrix stylites de Meyer, Z.W. de Beer \& M.J. Wingf., S. humicola de Meyer, Z.W. de Beer \& M.J. Wingf. and S. lignivora de Meyer, Z.W. de Beer \& M.J. Wingf. We suspect that Sporothrix sp. 1 may have a similar ecological niche as above mentioned species because this fungus was isolated from pine shoots laying often directly on the sandy soil.

\section{CONCLUSIONS}

The aim of this study was to characterize ophiostomatoid species associated with pine shoots damaged by Tomicus spp. in Poland. The diversity of reported was low, with seven species found. In addition, all the species were recorded at low frequencies. Our research show that the pine shoots damaged by Tomicus spp. beetles are poorly colonized by fungal associates of these insects. Only Ophiostoma minus, the most important associate of T. piniperda in Poland, was relatively often isolated from fallen pine shoots. Two other frequent species, Ophiostoma sp. 1 and Sporothrix sp. 1 probably represent undescribed taxa. This is also the first report of Ophiostoma floccosum from Poland.

Acknowledgement. We thank Wilhelm de Beer (Department of Microbiology and Plant Pathology, Forestry and Agricultural Biotechnology Institute (FABI), University of Pretoria, Pretoria, South Africa) for his assistance with species identification. 


\section{REFERENCES}

Borkowski A. 2001. Threats to pine stands by the pine shoot beetles Tomicus piniperda (L.) and T. minor (Hart.) around a sawmill in southern Poland. J. Appl. Entomol. 125: 489-492.

de Beer Z.W., Harrington T.C., Vismer H.F., Wingfield B.D., Wingfield M.J. 2003. Phylogeny of the Ophiostoma stenoceras-Sporothrix schenckii complex. Mycologia 95 (3): 434-441.

de Meyer E.M., de Beer Z.W., Summerbell R.C., Moharram A.M., de Hoog G.S., Vismer H.F., Wingfield M.J. 2008. Taxonomy and phylogeny of new wood- and soil-inhabiting Sporothrix species in the Ophiostoma stenoceras-Sporothrix schenckii complex. Mycologia 100 (4): 647-661.

Francke-Grosmann H. 1952. Über die Ambrosiazucht der beiden Kiefernborkenkäfer Myelophilus minor Htg. und Ips acuminatus Gyll. Meddn. St. Skogforsk. Inst. 41: 1-52.

Gibbs J.N., Inman A. 1991. The pine shoot beetle Tomicus piniperda as a vector of blue-stain fungi to windblown pine. Forestry 64: 239-249.

Glass N.L., Donaldson G.C. 1995. Development of primer sets designed for use with the PCR to amplify conserved genes from filamentous ascomycetes. Appl. Environ. Microbiol. 61: 1323-1330.

Greif M.D., Gibas C.F., Currah R.S. 2006. Leptographium piriforme sp. nov., from a taxonomically diverse collection of arthropods collected in an aspen-dominated forest in western Canada. Mycologia 98: 771-780.

Jankowiak R. 2006. Fungi associated with Tomicus piniperda in Poland and assessment of their virulence using Scots pine seedlings. Ann. For. Sci. 63: 801-808.

Jankowiak R. 2008. Fungi associated with Tomicus minor on Pinus sylvetris in Poland and their succession into the sapwood of beetle-infested windblown trees. Can. J. For. Res. 10: 2579-2588.

Jankowiak R., Kurek M. 2006. The early stages of fungal succession in Scots pine phloem and sapwood infested by the pine shoot beetle - Tomicus piniperda. Dendrobiology 56: 27-36.

Jankowiak R., Bilański P. 2007. Fungi associated with Tomicus piniperda L. in an area close to a timber yard in Poland. J. Appl. Entomol. 131 (8): 579-584.

Jankowiak R., Kolařík M. 2010a. Diversity and pathogenicity of ophiostomatoid fungi associated with Tetropium species (Coleoptera: Cerambycidae) colonizing Picea abies in Poland. Folia Microbiol. 55 (2): $145-154$.

Jankowiak R., Kolařík M. 2010b. Leptographium piriforme - first record for Europe and potential pathogenicity. Biologia 65 (4): 754-757.

Jankowiak R., Rossa R., Bilański P. 2007. Contribution to pathogenicity of three blue-stain fungi associated with the pine sawyer beetle Monochamus galloprovincialis (Coleoptera: cerambycidae) to Scots pine in Poland. Phytopathol. Pol. 46: 37-46.

Kirisits T. 2004. Fungal associates of European bark beetles with special emphasis on the ophiostomatoid fungi. (In:) F. Lieutier, K.R. Day, A. Battisti, J.C. Grégoire, H. Evans (eds). Bark and wood boring insects in living trees in Europe, a synthesis. Kluwer, Dordrecht: 185-223.

Kirisits T., Grubelnik R., Führer E. 1999. Die ökologische Bedeutung von Bläuepilzen für rindenbrütende Borkenkäfer. (In:) F. Müller (ed.). Mariabrunner Waldbautage 1999-Umbau sekundärer Nadelwälder. Schriftenreihe der Forstlichen Bundesversuchsanstalt Wien, FBVA-Berichte 111: 117-137.

Kolařík M., Sláviková E., Pažoutová S. 2006. The taxonomic and ecological characterization of the clinically important heterobasiodiomycete Fugomyces cyanescens and its association with bark beetles. Czech Mycol. 58: 81-98.

Kotýnková-Sychrová E. 1966. Mykoflóra chodeb kůrovců v Československu. Česká Mycol. 20: 45-53.

Lieutier F., Yart A., Garcia J., Ham M.C., Morelet M., Levieux J. 1989. Champignons phytopathogènes associés à deux coléoptères scolytidae du pin sylvestre (Pinus sylvestris L.) et étude préliminaire de leur agressivité envers l'hôte. Ann. Sci. For. 46: 201-216.

Linnakoski R., de Beer Z.W., Ahtiainen J., Sidorov E., Niemelä P., Pappinen A., Wingfield M.J. 2010. Ophiostoma spp. associated with pine- and spruce-infesting bark beetles in Finland and Russia. Persoonia 25: 72-93.

Mathiesen A. 1950. Über einige mit Borkenkäfern assoziierten Bläuepilze in Schweden. Oikos 2: 275308.

Mathiesen A. 1951. Einige neue Ophiostoma-Arten in Schweden. Sven. Bot. Tidsk. 45: 203-232.

Mathiesen-Käärik A. 1953. Eine Übersicht über die gewöhnlichsten mit Borkenkäfern assoziierten Bläuepilze in Schweden und einige für Schweden neue Bläuepilze. Meddn. St. Skogforsk. Inst. 43: 1-74. 
O'Donnell K., Cigelnik E. 1997. Two divergent intragenomic rDNA ITS2 types within a monophyletic lineage of the fungus Fusarium are nonorthologous. Mol. Phylogenet. Evol. 7: 103-116.

Solheim H., Långström B. 1991. Blue-stain fungi associated with Tomicus piniperda in Sweden and preliminary observations on their pathogenicity. Ann. Sci. For. 48: 149-156.

Solheim H., Långström B., Hellqvist C. 1993. Pathogenicity of the blue-stain fungi Leptographium wingfieldii and Ophiostoma minus to Scots pine: effect of tree pruning and inoculum density. Can. J. Forest Res. 23: 1438-1443.

Solheim H., Krokene P., Långström B. 2001. Effects of growth and virulence of associated blue-stain fungi on the host colonisation behaviour of pine shoot beetles Tomicus minor and T. piniperda. Plant Pathol. 50: 111-116.

Tamura K., Peterson D., Peterson N., Stecher G., Nei M., Kumar S. 2011. MEGA 5: Molecular Genetics Analysis using Maximum Likelihood, Evolutionary Distance and Maximum Parisimony Methods. Mol. Biol. Evol. 28 (10): 2731-2739.

Thompson J. D., Higgins D. G., Gibson T. J. 1994. Improving the sensitivity of progressive multiple sequence alignment through sequence weighting, position-specific gap penalties and weight matrix choice. Nucleic Acids Res. 22: 4673-4680.

Upadhyay H. 1981. A monograph of Ceratocystis and Ceratocystiopsis. The University of Georgia Press, Athens.

Wingfield M.J., Gibbs J.N. 1991. Leptographium and Graphium species associated with pine-infesting bark beetles in England. Mycol. Res. 95: 1257-1260.

Wingfield M.J., Seifert K.A., Webber J.F. 1993. Ceratocystis and Ophiostoma. Taxonomy, ecology and pathogenicity. American Phytopathological Society, St Paul, MN.

\section{Grzyby z rodzaju Ophiostoma s.l. wyizolowane z opadłej cetyny sosnowej w Polsce}

\section{Streszczenie}

Grzyby należące do grupy gatunków w przeszłości zaliczanych do rodzaju Ophiostoma s.l. są znane ze współżycia z owadami z rodzaju Tomicus żerującymi na sośnie zwyczajnej Pinus sylvestris L. Jednakże bardzo mało wiemy o grzybach występujących w pędach sosny, uszkodzonych przez te owady. Celem badań było poznanie składu gatunkowego i frekwencji występowania grzybów z tej grupy związanych z pędami sosny zwyczajnej uszkodzonymi przez żer uzupełniający cetyńców. Badania przeprowadzono w latach 2007-2008 w czterech drzewostanach sosnowych zlokalizowanych w różnych częściach Polski. Grzyby były identyfikowane na podstawie cech morfologicznych, a wybrane, reprezentatywne szczepy grzybów poddano także amplifikacji i sekwencjonowaniu fragmentów ITS1, 5.8S, ITS2 oraz fragmentów genu ß-tubuliny. Ogółem, z pędów uszkodzonych przez cetyńce, otrzymano 64 izolaty grzybów reprezentujące siedem gatunków grzybów należących do Ophiostoma s.l. Dwa z nich, Ophiostoma sp. 1 i Sporothrix sp. 1 prawdopodobnie reprezentują taksony nowe dla nauki. Niepewny pozostaje również status taksonomiczny izolatu zaklasyfikowanego jako Grosmannia cucullata-like.

Wszystkie stwierdzone gatunki charakteryzowały się niską częstością występowania. Wśród nich, Ophiostoma minus, Ophiostoma sp. 1 i Sporothrix sp. 1 były izolowane z $2.0 \%$ pędów. Pozostałe gatunki grzybów (Leptographium piriforme, Ophiostoma canum, O. floccosum i Grosmannia cucullata-like) zasiedlały pędy sosny sporadycznie. Wśród zidentyfikowanych grzybów $O$. floccosum, Ophiostoma sp. 1 i Sporothrix sp. 1 zostały stwierdzone w Polsce po raz pierwszy. 